\title{
Relative maturity group and its relationships with the non preferential sowing season in soybean
}

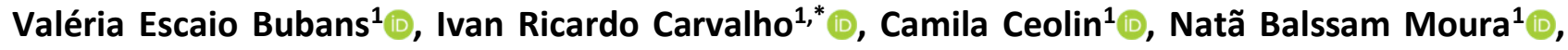 \\ Francine Lautenchleger ${ }^{2}{ }^{-}$, Gerusa Massuquini Conceição ${ }^{1}{ }^{(0}$, José Antonio Gonzalez Da Silva ${ }^{1}($ ) \\ and Renan Jardel Rusch Treter $^{1}(\mathbb{B}$
}

${ }^{1}$ Universidade Regional do Noroeste do Estado do Rio Grande do Sul (Unijuí), ljuí, Brazil. ${ }^{2}$ Universidade Estadual do Centro-Oeste (Unicentro), Guarapuava, PR, Brazil. *Corresponding author, E-mail: carvalho.irc@gmail.com

\begin{abstract}
The cultivation of soybeans is the main agricultural commodity in Brazil, the increase in the cultivated area in recent years and the productivity of grains is interconnected with numerous factors such as sowing time, water availability, temperature and photoperiod. The objective of this work was to evaluate the duration of phenological sub-periods and the productivity of soybean cultivars from different groups of relative maturation, sown in two seasons in the off-season in the northwest region of the State of Rio Grande do Sul (RS). The experiment was carried out at Agropecuária Bubans geographically located in the county of ljuí in the state of RS, considered medium locality. The experiment was carried out using a randomized block design with four replications, the experimental units consisted of four lines, four meters long, $0.50 \mathrm{~m}$ apart. The treatments were eight soybean cultivars with different groups of relative maturity $(4.8,5.8,5.9,6.2$, 6.3, 6.4, 6.7 and 7.8) sown on January 5 and 22, 2019 (from agricultural zoning, the preferred season for sowing in this region is from october to december), constituting an $8 \times 2$ factorial experiment (Cultivars $x$ sowing times). Assessments of the duration of phenological sub-periods and of the yield components of the culture were carried out, being measured with total plant height, first pod insertion height, number of lateral branches, number of reproductive nodes on the main stem, total number of nodes on the main stem, number of pods with one, two, three and four grains, pods mass of one, two, three and four grains, total grain mass per plant, thousand seed mass and grain yield. The most productive relative maturity group is 6.3 being sown in the first non-preferential season for soybeans in Rio Grande do Sul. The second sowing time changed the dynamics of association of the measured variables, with changes in the cycle, reductions in the vegetative and reproductive period.
\end{abstract}

Keywords: Strategic positioning, contrasting growth and development, production system, development cycle, management practices, photoperiodic sensitivity.

\section{INTRODUCTION}

Soybean is one of the main crops of agriculture, with a relevant socioeconomic role, with Brazil being the second largest world producer of oilseeds. In the 2018/2019 harvest, the crop occupied an area of 35.8 million hectares in the country, with a $1.9 \%$ increase in planted area compared to the previous harvest, with an estimated production of 114.4 million tons of grains (Companhia Nacional de Abastecimento [CONAB], 2019; Hanyu, Costa, Cecon, \& Matsuo, 2020; Soares, Sediyama, \& Matsuo, 2020; Ferreira et al., 2020; Frota et al., 2020; Carvalho et al., 2021).

This increase in grown area and soybean yield in Brazil is due to the incorporation of new technologies to the production system, such as the use of early cultivars (maturity group less than 6.4), with an undeterminate growth type, in substitution of cultivars from medium to long cycle, with determinate growth type (Zanon et al., 2015). It should also be noted that the increase in production in Rio Grande do Sul (RS) is due to the fact that many farmers are carrying out early (late September and early October) and late (late December and January) sowing, thus allowing two crops in the same crop season (Meotti, Raphael, Beche, \& Munaro, 2012). Soybean is a short-day plant, influenced by the photoperiodic conditions characteristic of each latitude, especially with regard to the duration of the period of emergence to flowering, and, as the photoperiod decreases, the available solar radiation also decreases (hours of light) (Ting-ting et al, 2015).

This photoperiodic sensitivity varies with the genotype, and the degree of response to the photoperiodic 
stimulus is the main determinant of the adaptation area of the different cultivars. In sensitive soybean cultivars, the response to the photoperiod is quantitative, not absolute, which means that flowering will occur anyway. However, the time required for this will depend on the length of the day, induction is quicker on short days than on long days. In this way, floral induction causes the transformation of vegetative meristems (differentiation of stems and leaves) into reproductive ones (floral origins), determining the final size of the plants (number of nodes) and, therefore, their yield potential (Rodrigues, Didonet, Lhamby, Bertagnolli, \& Luz, 2001).

With the relative maturity groups (RMG) classification, based on the response to the photoperiod, management and general area of adaptation of soybean cultivars, it made it possible to visualize in a more realistic way the factors that affect the duration of the development cycle. When cultivars with different RMGs are sown in the same region, it is expected that the higher the RMG, the longer the development cycle of this cultivar will be (Zanon et al., 2015). When the sowing time is delayed, there is a reduction in the duration of the development cycle, regardless of the RMG of the cultivar. From this new classification of cultivars through RMGs, the precision in estimating the duration of the development cycle of soybean cultivars sown near the first half of November is greater (Zanon et al., 2018). Despite this advance, RMG is not able to have a good precision in representing the duration of the development cycle in sowing carried out at the end of September and beginning of October or even after the second half of December, due to the variation in temperature and photoperiod, with the time of sowing crops (Zanon et al., 2015) especially in subtropical regions, such as the southern region of Brazil and part of Argentina.

However, this grain yield is intertwined with numerous factors such as sowing time, water availability, temperature, photoperiod and available solar radiation. Noting that, throughout the soybean growing season in the state of RS, the intensity of solar radiation, photoperiod and average air temperature increase in the months from September to December, and decrease in the months from January to April (Zanon et al., 2015), therefore, the choice of cultivar that adapts to the place and the sowing season is extremely important, since cultivars sown at inappropriate times do not express their full growth potential, and consequently, its productive potential.

Thus, studies are needed that describe in detail the development of soybean cultivars, in response to the different edaphoclimatic availabilities in Rio Grande do Sul and Brazil. This is because with the characterization of the duration of the phases and the development cycle, depending on the maturity group and the type of growth, there is extremely relevant information, which becomes support tools for technicians and farmers in the decision making of which management practices to carry out, to reach the productive potential of each cultivar (Zanon et al., 2015). Mainly studies related to the development and productive performance of soybean cultivars sown in the off-season, since they are scarce, not allowing the desirable clarification of the subject (Braccini et al., 2003).

In this sense, the objective of this study was to evaluate the duration of phenological sub-periods, development and yield of soybean cultivars in the off-season period containing different maturity groups grown in two seasons in Rio Grande do Sul, Brazil.

\section{MATERIAL AND METHODS}

The experiment was carried out at Agropecuária Bubans geographically located in the county of ljuí in the state of Rio Grande do Sul, at $28^{\circ} 29^{\prime} 11^{\prime \prime} \mathrm{S} 53^{\circ} 50^{\prime} 44^{\prime \prime}$ W, with an altitude close to 328 meters above sea level, with a soil classified as Red Latosol (Oxisol). The climate of the region is classified as Cfa (subtropical humid) according to the climatic classification of Köeppen, being characterized by the occurrence of hot summers and without prolonged droughts, with cold and humid winter, with frequent occurrence of frosts. With regard to annual rainfall, they are around $1600 \mathrm{~mm}$, with greater rainfall in the winter period.

The experiment was carried out using a randomized block design with four replications, the experimental units consisted of four lines, four meters long, $0.50 \mathrm{~m}$ apart $\left(8 \mathrm{~m}^{2}\right)$. The treatments were eight soybean cultivars with different groups of relative maturity $(4.8,5.8,5.9,6.2,6.3,6.4,6.7$ and 7.8$)$ (Table 1) sown on January 5 and 22,2019, constituting an $8 \times 2$ factorial experiment (Cultivars $\times$ sowing times). The relative maturity group (GMRs) is the duration of the soybean development cycle (sowing to physiological maturity). This classification in GMRs allows the indication of cultivars for each region of cultivation, with the duration of the development cycle between 125 to 140 days for all GMRs. When cultivars with different GMRs are sown in the same location, it is expected that the higher the GMR, the longer the cultivar's development cycle will last (Zanon et al., 2015). However, when the sowing time is delayed, there is a reduction in the duration of the development cycle, regardless of the GMR of the cultivar. 
The seeds were treated with Pyraclostrobin, Methyl Thiophanate and Fipronil in the dosage of $200 \mathrm{ml} / 100$ $\mathrm{kg}$ of seeds being the main products used for the treatment of seeds in this region and inoculated with Bradyhizobium japonicum, using the peat inoculant in the proportion of $250 \mathrm{~g}$ of inoculant per $50 \mathrm{~kg}$ of seed $(600,000$ bacteria/seed), on the day of sowing in order to subsequently perform biological nitrogen fixation. Fertilization management was carried out based on soil analysis and recommendation of the liming and fertilization manual for the states of Rio Grande do Sul and Santa Catarina, using $350 \mathrm{~kg} \mathrm{ha}^{-1}$ of the formula fertilizer 2-23-23. The management of invasive plants, diseases and pest insects were carried out preventively in order to minimize the biotic effects in the experiment.

Table 1. Soybean cultivars, maturity group and growth habit described by breeders.

\begin{tabular}{lcc}
\hline Cultivars & RMG & Growth habit \\
\hline NS 4823 RR & 4.8 & Indeterminate \\
DM 5958 RSF IPRO & 5.8 & Indeterminate \\
M 5947 IPRO & 5.9 & Indeterminate \\
TMG 6203 IPRO & 6.2 & Semi-determinate \\
LG 60163 IPRO & 6.3 & Semi-determinate \\
M 6410 IPRO & 6.4 & Indeterminate \\
6968 RSF (Brasmax Valente) & 6.7 & Indeterminate \\
TEC 7849 IPRO & 7.8 & Indeterminate \\
\hline
\end{tabular}

To evaluate the phenology of the crop, five plants were selected at random in each plot evaluated daily based on the phenological scale of soybean, proposed by Fehr and Caviness (1977), being evaluated the duration in days of the following development periods: Emergence (VE), Emergence - R1 (VE - R1), R1 - R3, R3 - R5, R5 - R7, R8 - Harvest (R8 - C), R1 - R5, R1 - 8 and Emergence - R8 (VE - R8) for different RMGs at both sowing times.

For the evaluation of the yield components, ten plants were evaluated per plot in R8, with total plant height $(\mathrm{PH}, \mathrm{cm})$, first pod insertion height $(\mathrm{FPIH}, \mathrm{cm})$, number of lateral branches (NLB, units), number of reproductive nodes on the main stem (NRNMS, units), total number of nodes on the main stem (TNNMS, units) number of reproductive nodes on the lateral branches (NRNLB, units), number of total nodes on the lateral branches (TNNLB, units), number of pods on the main stem (NPMS, units), number of pods on the lateral branches (NPLB, units), lateral branch length (LBL, cm), number of pods with one, two, three and four grains (NP1, NP2, NP3, NP4, units), pods mass of one, two, three and four grains (PM1, PM2, PM3, PM4, g), number of pods on lateral branches of one, two, three and four grains (NPLB1, NPLB2, NPLB3, NPLB4, units ), pod mass on lateral branches with one, two, three and four grains (PMLB1, PMLB2, PMLB3, PMLB4, units), total grain mass per plant (TGM, g), thousand seed mass (TSM, g) and grain yield (GY, kg ha$\left.{ }^{1}\right)$. After the whole plot was harvested manually. It was tracked and cleaned to measure weight and correct grain moisture to $13 \%$.

The data were submitted to the assumptions of the statistical model, normality, homogeneity and additivity of the model, afterwards the analysis of variance was carried out in order to identify significant interaction between non-preferential sowing times $x$ groups of relative soybean maturity, these significant were dismembered to the simple effects by the Tukey probability matrix. After, the phenotypic linear correlation with significance based on $5 \%$ of specific probability for each sowing period was evidenced, as well as, the linear correlation between the agronomic attributes of interest and the definitions of the plastochrome at $5 \%$ of specific probability, using the average Euclidean algorithm to construct the dendrogram and the Biplot main components to define affinities of the sources of variation with the measured variables using software $R$.

\section{RESULTS AND DISCUSSION}

The results obtained for eight soybean cultivars from different maturity groups sown in two sowing dates, considered as off-season soybeans because they are outside the recommended sowing time for the crop 
that covers the period from early September to the end of December, according to Ordinance No. 154, OF JULY 25, 2018. There was a significant effect for the interaction between sowing time $x$ relative maturity group ( $T \times R M G$ ) and also significant effect for RMG alone, for all variables except for number of pods with four grains (NP4), pod mass with one grain (PM1), pod mass with four grains (PM4), number of pods on the lateral branch with four grains (NPLB4) and pod mass on the lateral branch with four grains (PMLB4). For the isolated season effect, the variables that showed significance were the pod mass with one grain (PM1), total grain mass (TGM), thousand seed mass (TSM) and grain yield (GY) and for the treatment RMG alone, the variables that showed significance were the number of pods with 3 grains (NP3), pod mass with 4 grains (PM4) and grain yield (GY) (Table 2).

For the variables total plant height (PH) as the RMG increase occurs, tends to increase the plant height within the season and when compared to the seasons as sowing is delayed, the plant has a lower height, this is also associated with the variable first pod insertion height (FPIH) (Table 3). Studies carried out by Peixoto et al. (2000) affirm that in late sowing for smaller RMGs, there is early flowering, reduced cycle and plant height. Thus, the shorter the exposure of the plants to long photoperiods, the flowering will occur in advance when the plant still has low vegetative size.

For the variables total number of nodes on the main stem (TNNMS) and reproductive nodes (NRNMS) in addition to the number of total nodes on the lateral branches (TNNLB), number of reproductive nodes on the lateral branches (NRNLB) and lateral branch length (LBL) showed a reduction, as a consequence of the lower plant height, which directly influences the final yield of these cultivars. This is because the delay of the second season for the off-season causes the plant to reduce its morphological structures due to the reduction of the vegetative period, which can also compromise its reproductive structures.

The number of nodes is one of the indirect components of yield and is associated with the evolution of the leaf area of the plant that intercepts solar radiation used in photosynthesis, whose process refers to the production and accumulation of phytomass, and that determines grain yield (Streck, Paula, Camera, Menezes, \& Lago, 2008). The final number of nodes is one of the most important development variables because it is linked to the duration of the plant cycle, and because it is the place where pods are associated. As soybean plants respond to the photoperiod, changing their cycle according to the photoperiod in which they are submitted, according to studies carried out by Weber (2017) 19 knots per plant would correspond to the production potential of $6.0 \mathrm{Kg} \mathrm{ha}^{-1}$.

For the variable NP1, the cultivars with RMG that stood out with this greatest characteristic, in the first season were: 5.8, 5.9, 6.2 and 6.7 and in the second season were 5.8, 5.9 and 6.4. For the number of pods on the branches with one grain (NPLB1), the cultivars that stood out were 5.8, 5.9, 6.3 and 6.4 in the first season, this may have been a response to some type of stress suffered by the plant. For NP2, cultivars with RMG 6.7 and 7.8 stood out for the first sowing season, whereas for the second the cultivars did not differ. For the number of pods on the branches with two grains, (NPLB2) the cultivars that stood out were those with RMG 6.3 in the first season and 6.2 and 6.4 in the second season. This variable being the one that presents the least variation between different growing situations (Mundstock \& Thomas, 2005). Several works show a uniform improvement in the search for plants with an average production of two to three grains per pod. According to Weber (2017), the average value of two grains per pod, remains a value that allows reaching high yields.

For NP3, cultivars with RMG of 5.8, 5.9, 6.2 and 6.3 were the ones that stood out for the first sowing season, while for the second were cultivars with RMG of 5.8, 5.9 and 6.7. For the number of pods on the branch with three grains (NPLB3), the cultivars that showed the best performance were with RMG of 5.9, $6.3,6.4$ in the first season and 6.2 and 6.4 in the second season. What may be related to the duration of the period between R1 and R5, where translocation of this photoassimilates occurs for the formation of pods and grain filling, a period favored by weather conditions, without problems of water stress.

For the variables number of pods on the main stem (NPMS) cultivars with RMG 6.2 and 6.7 in the first season and 5.8, 5.9 and 6.7 for the second season and for the number of pods on the branches (NPLB) for cultivars with RMG 6.3 in the first season and 6.2 and 6.4 in the second season, it can be observed in general for these variables as the RMG increases, consequently the number of pods increases, due to the increase in plant height, as previously reported and when sowing is extended, the plant tends to develop fewer pods due to less crop growth. This component of yield can be considered the most variable with the modification of the plant arrangement, suffering the greatest modifications through the use of management practices, since the amount of pods is dependent on the amount of flowers produced and fixed during the crop reproductive period (Mundstock \& Thomas, 2005).

For the variables of pod mass with two grains (PM2), the cultivars that stood out were with RMG 4.8 for the

Agronomy Science and Biotechnology, Rec. 121, Volume 7, Pages 1-14, 2021 
first sowing season and for the second season were those with 5.8, 5.9, 6.2, 6.3, 6.7, and 7.8. For the pod mass with three grains (PM3), the RMG that stood out in the first season were 6.2 and 6.3 and in the second season were cultivars 5.8, 5.9, 6.3 and 6.4. For the pod mass on the branches with one grain (PMLB1), the cultivars with the highest averages were those with RMG 5.2 and 5.9 only for the first sowing season, for the second it was not significant. For the pod mass on the branches with two grains (PMLB2) and three grains (PMLB3) the cultivars that stood out for the first season were those with RMG of 6.3 and for the second season they were those with 6.2 and 6.4, for both variables. The grain mass and the number of grains per pod are components influenced by genetics and the environment (Hanway \& Thompson, 1994).

Regarding the thousand seed mass (TSM) in both sowing times, the cultivar 7.8 presented greater mass, being this related to the genetic characteristics of the cultivar (Pandey \& Torrie, 1973), but which depends on the environment (precipitation, mainly) and management (sowing density and protection against the attack of sucking insects and diseases) to express its potential. According to studies carried out by Weber (2017), the thousand grain mass that maximizes yield is $190 \mathrm{~g}$, however, stresses in the grain filling phase, can influence the final grain mass.

Analyzing the grain yield variable, we found that for the first season, the RMG 6.7 and 6.3 cultivars showed the highest yields, with 3853.24 and $3802.16 \mathrm{~kg} \mathrm{ha}^{-1}$ respectively. For the second sowing season, the RMG 6.3 cultivar was the most productive with $3516.66 \mathrm{~kg} \mathrm{ha}^{-1}$. Since grain yield is a complex variable, which expresses the interaction of genetics with the environment and is directly related to management practices (sowing density, seed quality, positioning of cultivars, etc.), which can enhance grain yield.

The use of linear correlations (Figure 1) aims to demonstrate the relationship between two variables, the correlation for the first sowing season, to increase grain yield (GY), there is an increase in the number of reproductive nodes of the stem (NRNMS), thus indirectly influencing the number of pods per plant, which is one of the components of crop yield. Plants with a higher total plant height $(\mathrm{PH})$ tend to have a higher first pod insertion height (FPIH). To increase the number of lateral branches (NLB), there is an increase in the number of reproductive nodes on the lateral branches (NRNLB), lateral branch length (LBL) and a reduction in the number of pods with two grains (NP2).

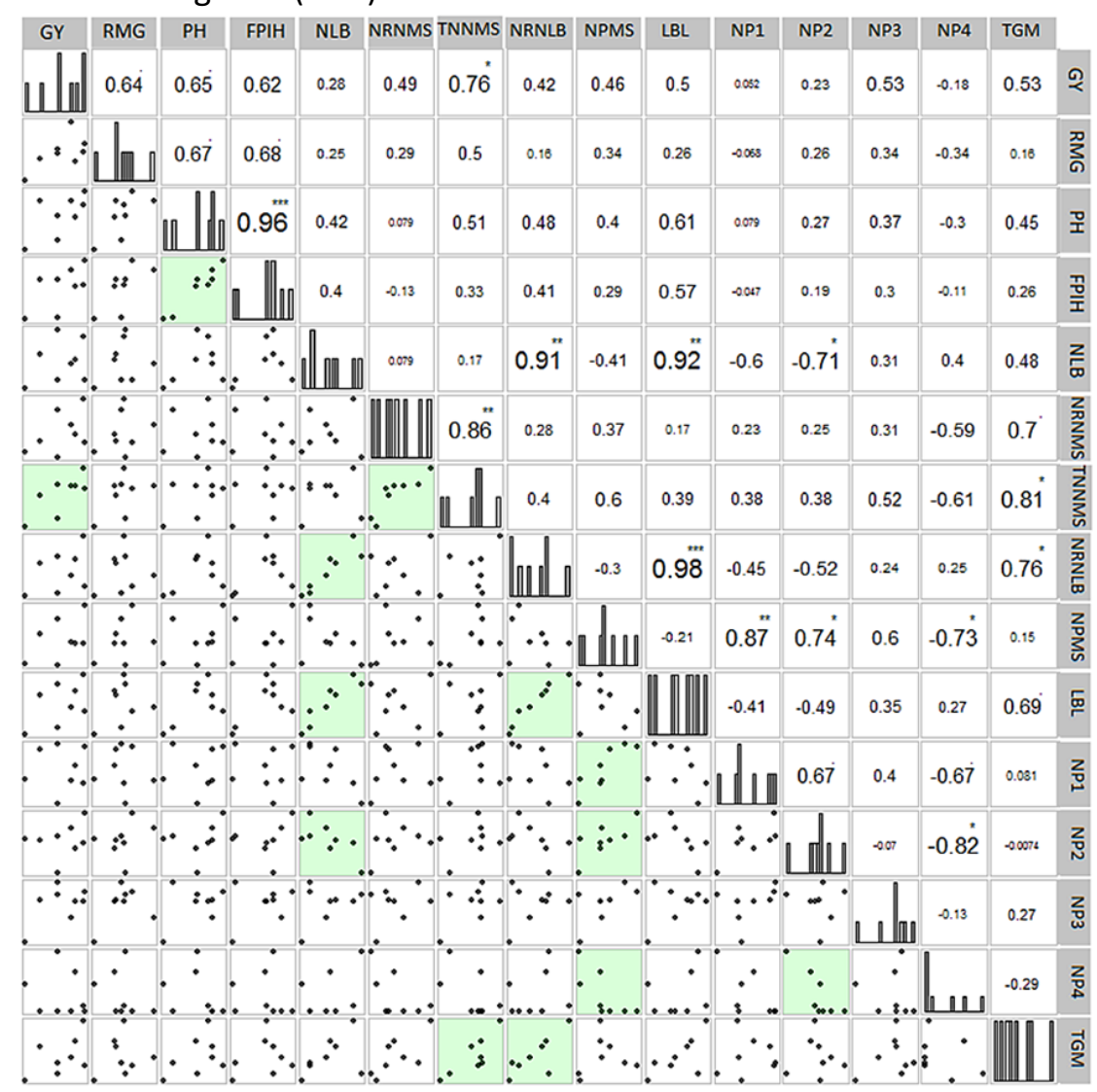

Figure 1. Phenotypic linear correlations for the effects of the first sowing season x relative maturity group. * significant at $5 \%$ probability by t test. GY: grain yield $\mathrm{kg} / \mathrm{ha}^{-1}$; RMG: relative maturity group; PH: total plant height; FPIH: first pod insertion height; NLB: number of lateral branches; NRNMS: number of reproductive nodes on the main stem; TNNMS: total number of nodes on the stem nodes; NRNLB: number of reproductive nodes on the lateral branches; NPMS: number of pods on the main stem; LBL: lateral branch length; NP1, NP2, NP3, NP4: number of pods with one, two, three and four grains; TGM: total grain mass per plant. 
Table 2. Summary of the analysis of variance for the interaction between non-preferred sowing times $\mathrm{x}$ maturity group at $5 \%$ probability.

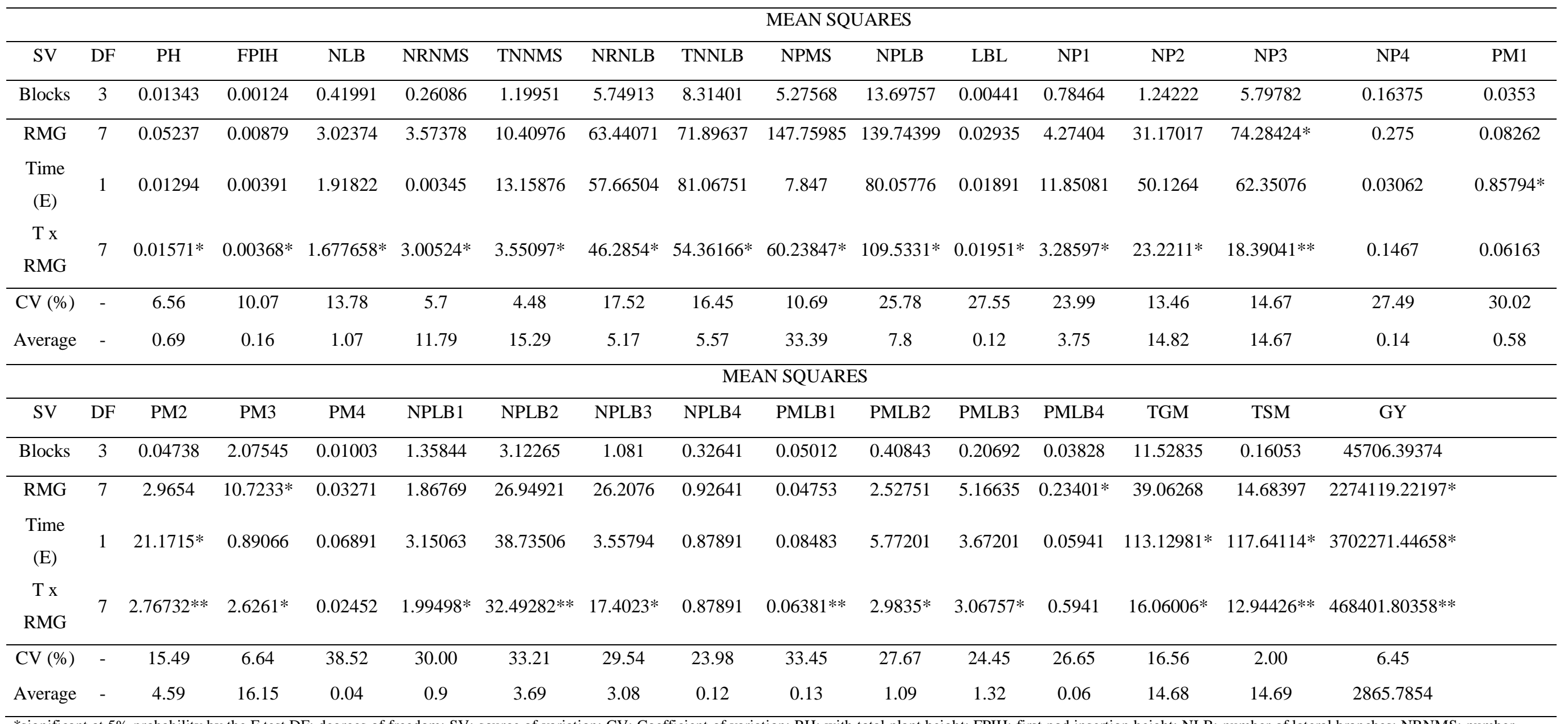

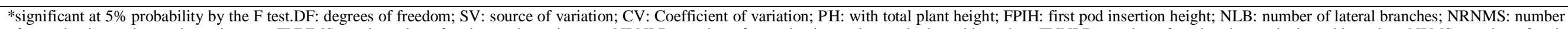

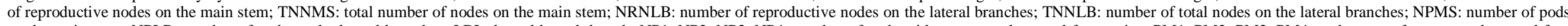

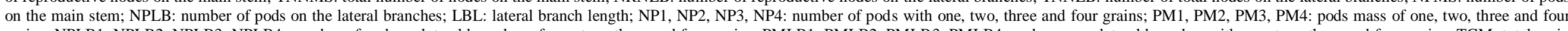

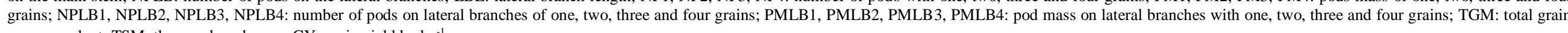
mass per plant; TSM: thousand seed mass; GY: grain yield $\mathrm{kg} \mathrm{ha}^{-1}$. 
Table 3: Average for the effects of the interaction between non-preferred sowing times $\mathrm{x}$ relative maturity group.

\begin{tabular}{|c|c|c|c|c|c|c|c|c|}
\hline \multicolumn{9}{|c|}{ Non-preferred sowing times } \\
\hline & $\operatorname{Jan} 5$ & Jan 22 & Jan 5 & Jan 22 & $\operatorname{Jan} 5$ & $\operatorname{Jan} 22$ & $\operatorname{Jan} 5$ & Jan 22 \\
\hline RMG & \multicolumn{2}{|c|}{$\mathrm{PH}$} & \multicolumn{2}{|c|}{ FPIH } & \multicolumn{2}{|c|}{ NP3 } & \multicolumn{2}{|c|}{ PM2 } \\
\hline 4.8 & $0.5475 \mathrm{cA}$ & $0.4900 \mathrm{cA}$ & $0.1200 \mathrm{cA}$ & $0.0875 \mathrm{eB}$ & $7.8000 \mathrm{cB}$ & $11.8750 \mathrm{cA}$ & $5.5100 \mathrm{aA}$ & $4.3250 \mathrm{aB}$ \\
\hline 5.8 & $0.7000 \mathrm{bA}$ & $0.6900 \mathrm{aA}$ & $0.1700 \mathrm{bA}$ & $0.1275 \mathrm{~dB}$ & $14.0250 \mathrm{aB}$ & $18.3500 \mathrm{aA}$ & $4.7350 \mathrm{aA}$ & $3.9150 \mathrm{aA}$ \\
\hline 5.9 & $0.7750 \mathrm{aA}$ & $0.6150 \mathrm{bB}$ & 0.1775 bA & 0.1025 eB & $14.2500 \mathrm{aB}$ & $18.6000 \mathrm{aA}$ & $5.4625 \mathrm{aA}$ & $4.5125 \mathrm{aA}$ \\
\hline 6.2 & $0.5950 \mathrm{cB}$ & $0.7200 \mathrm{aA}$ & $0.1225 \mathrm{cB}$ & $0.1475 \mathrm{dA}$ & $17.000 \mathrm{aA}$ & $15.6750 \mathrm{bA}$ & $5.3275 \mathrm{aA}$ & $3.3200 \mathrm{aB}$ \\
\hline 6.3 & $0.7550 \mathrm{aA}$ & $0.7225 \mathrm{aA}$ & $0.1700 \mathrm{bA}$ & $0.1675 \mathrm{cA}$ & $14.1575 \mathrm{aA}$ & $15.7000 \mathrm{bA}$ & $5.4750 \mathrm{aA}$ & $3.6450 \mathrm{aB}$ \\
\hline 6.4 & $0.7100 \mathrm{bA}$ & $0.7700 \mathrm{aA}$ & $0.1800 \mathrm{bB}$ & $0.2325 \mathrm{aA}$ & $15.1250 \mathrm{aA}$ & $14.8250 \mathrm{bA}$ & $2.6600 \mathrm{bB}$ & $4.1625 \mathrm{aA}$ \\
\hline 6.7 & $0.8150 \mathrm{aA}$ & $0.7550 \mathrm{aA}$ & 0.2075 aA & $0.1425 \mathrm{~dB}$ & $15.6250 \mathrm{aB}$ & 21.2000 aA & $5.7375 \mathrm{aA}$ & $3.7500 \mathrm{aB}$ \\
\hline 7.8 & 0.7775 aA & $0.6850 \mathrm{aB}$ & $0.1950 \mathrm{aA}$ & $0.1900 \mathrm{bA}$ & $11.5000 \mathrm{bA}$ & $9.0500 \mathrm{cA}$ & $6.4325 \mathrm{aA}$ & $4.5075 \mathrm{aB}$ \\
\hline RMG & \multicolumn{2}{|c|}{ NLB } & \multicolumn{2}{|c|}{ NRNMS } & \multicolumn{2}{|c|}{ PM3 } & \multicolumn{2}{|c|}{ NPLB1 } \\
\hline 4.8 & $0.1750 \mathrm{dA}$ & $0.0000 \mathrm{bA}$ & $10.8750 \mathrm{cA}$ & $11.3500 \mathrm{bA}$ & $4.0675 \mathrm{cA}$ & $5.1225 \mathrm{cA}$ & $0.0250 \mathrm{bA}$ & $0.000 \mathrm{aA}$ \\
\hline 5.8 & $1.3000 \mathrm{cA}$ & $0.9250 \mathrm{bA}$ & $11.7250 \mathrm{cA}$ & $12.6500 \mathrm{aA}$ & $6.8825 \mathrm{bA}$ & $8.1050 \mathrm{aA}$ & $2.3000 \mathrm{aA}$ & $0.5500 \mathrm{aB}$ \\
\hline 5.9 & $1.5250 \mathrm{bA}$ & $0.4759 \mathrm{bB}$ & $11.4000 \mathrm{cB}$ & $13.1500 \mathrm{aA}$ & $6.9725 \mathrm{bA}$ & $7.4875 \mathrm{aA}$ & $1.2250 \mathrm{aA}$ & $0.5500 \mathrm{aB}$ \\
\hline 6.2 & $0.5250 \mathrm{~dB}$ & $2.1250 \mathrm{aA}$ & $12.8500 \mathrm{aA}$ & $11.1750 \mathrm{bB}$ & $7.8275 \mathrm{aA}$ & $6.2475 \mathrm{bB}$ & $0.2500 \mathrm{bB}$ & $1.6750 \mathrm{aA}$ \\
\hline 6.3 & $2.2250 \mathrm{aA}$ & $0.9750 \mathrm{bB}$ & $13.4250 \mathrm{aA}$ & $11.9500 \mathrm{aB}$ & $8.0300 \mathrm{aA}$ & $7.9950 \mathrm{aA}$ & $2.0250 \mathrm{aA}$ & $0.4000 \mathrm{aB}$ \\
\hline 6.4 & $2.5250 \mathrm{aA}$ & $1.6250 \mathrm{aB}$ & $10.5750 \mathrm{cA}$ & $10.6250 \mathrm{bA}$ & 5.8475 bA & $6.5050 \mathrm{bA}$ & $1.7325 \mathrm{aA}$ & $1.2000 \mathrm{aA}$ \\
\hline 6.7 & $0.5200 \mathrm{dA}$ & $0.6750 \mathrm{bA}$ & $11.3075 \mathrm{cA}$ & $12.1750 \mathrm{aA}$ & $6.5125 \mathrm{bA}$ & $7.9375 \mathrm{aA}$ & $0.6425 \mathrm{bA}$ & $0.5500 \mathrm{aA}$ \\
\hline 7.8 & $1.1500 \mathrm{cA}$ & $0.3750 \mathrm{bB}$ & $12.1500 \mathrm{bA}$ & $11.3500 \mathrm{bA}$ & $6.0775 \mathrm{bA}$ & $4.7250 \mathrm{cA}$ & $0.8000 \mathrm{bA}$ & $0.5250 \mathrm{aA}$ \\
\hline RMG & \multicolumn{2}{|c|}{ TNNMS } & \multicolumn{2}{|c|}{ NRNLB } & \multicolumn{2}{|c|}{ NPLB2 } & \multicolumn{2}{|c|}{ NPLB3 } \\
\hline 4.8 & $13.025 \mathrm{cA}$ & $12.8000 \mathrm{cA}$ & $1.0000 \mathrm{dA}$ & $0.0000 \mathrm{cA}$ & $0.7750 \mathrm{cA}$ & $0.0000 \mathrm{bA}$ & $0.6750 \mathrm{bA}$ & $0.000 \mathrm{bA}$ \\
\hline 5.8 & $16.3750 \mathrm{bA}$ & $15.8500 \mathrm{aA}$ & 8.5250 bA & $4.0250 \mathrm{cB}$ & $6.5750 \mathrm{bA}$ & $3.1500 \mathrm{bB}$ & $3.450 \mathrm{bA}$ & $2.1000 \mathrm{bA}$ \\
\hline 5.9 & $15.6750 \mathrm{bA}$ & $15.9000 \mathrm{aA}$ & $7.6000 \mathrm{bA}$ & $2.2500 \mathrm{cB}$ & $5.1250 \mathrm{bA}$ & $1.8500 \mathrm{bB}$ & $4.9000 \mathrm{aA}$ & $1.4250 \mathrm{bB}$ \\
\hline 6.2 & $16.5500 \mathrm{bA}$ & $15.0000 \mathrm{bB}$ & $1.5750 \mathrm{~dB}$ & $9.8250 \mathrm{aA}$ & $1.4500 \mathrm{cB}$ & $7.6500 \mathrm{aA}$ & $1.0750 \mathrm{bA}$ & $7.1000 \mathrm{aA}$ \\
\hline 6.3 & $17.9250 \mathrm{aA}$ & $15.0750 \mathrm{bB}$ & $12.9750 \mathrm{aA}$ & $5.4000 \mathrm{bB}$ & $9.8750 \mathrm{aA}$ & $1.9750 \mathrm{bB}$ & $6.6500 \mathrm{aA}$ & $3.5500 \mathrm{bB}$ \\
\hline 6.4 & $13.7750 \mathrm{cB}$ & $15.0250 \mathrm{bA}$ & $9.1250 \mathrm{bA}$ & $7.2500 \mathrm{bA}$ & $5.39550 \mathrm{bA}$ & $5.2250 \mathrm{aA}$ & $6.1350 \mathrm{aA}$ & $5.2250 \mathrm{aA}$ \\
\hline 6.7 & $16.2050 \mathrm{bA}$ & $14.6750 \mathrm{bB}$ & $2.9875 \mathrm{dA}$ & $3.3000 \mathrm{cA}$ & $2.3525 \mathrm{cA}$ & $2.2750 \mathrm{bA}$ & $1.6375 \mathrm{bA}$ & $2.3750 \mathrm{bA}$ \\
\hline 7.8 & $16.4500 \mathrm{bA}$ & $14.4000 \mathrm{bB}$ & $5.2250 \mathrm{cA}$ & $1.7750 \mathrm{cB}$ & $4.2000 \mathrm{bA}$ & $1.1750 \mathrm{bB}$ & $2.0750 \mathrm{bA}$ & $1.0500 \mathrm{bA}$ \\
\hline RMG & \multicolumn{2}{|c|}{ TNNLB } & \multicolumn{2}{|c|}{ NPMS } & \multicolumn{2}{|c|}{ PMLB1 } & \multicolumn{2}{|c|}{ PMLB2 } \\
\hline 4.8 & $1.1250 \mathrm{dA}$ & $0.0000 \mathrm{cA}$ & $27.8500 \mathrm{cA}$ & $30.0750 \mathrm{bA}$ & $0.0050 \mathrm{bA}$ & $.0000 \mathrm{aA}$ & $0.2375 \mathrm{dA}$ & $0.0000 \mathrm{bA}$ \\
\hline 5.8 & $9.7500 \mathrm{bA}$ & $4.2000 \mathrm{bB}$ & $32.8500 \mathrm{bA}$ & $37.8500 \mathrm{aA}$ & $0.3850 \mathrm{aA}$ & $0.0850 \mathrm{aB}$ & $2.1850 \mathrm{bA}$ & $0.8175 \mathrm{bB}$ \\
\hline 5.9 & $8.3000 \mathrm{bA}$ & $2.3000 \mathrm{cB}$ & $35.2500 \mathrm{bA}$ & $38.9500 \mathrm{aA}$ & $0.2425 \mathrm{aA}$ & $0.0650 \mathrm{aA}$ & $1.8600 \mathrm{bA}$ & $0.4450 \mathrm{bB}$ \\
\hline 6.2 & $1.7500 \mathrm{~dB}$ & $10.3750 \mathrm{aA}$ & $38.9000 \mathrm{aA}$ & $31.4250 \mathrm{bB}$ & 0.0375 bA & $0.1875 \mathrm{aA}$ & $0.4325 \mathrm{~dB}$ & $1.8675 \mathrm{aA}$ \\
\hline 6.3 & $13.8750 \mathrm{aA}$ & $5.5000 \mathrm{bB}$ & $32.7925 \mathrm{bA}$ & $29.2000 \mathrm{bA}$ & $0.3825 \mathrm{aA}$ & $0.0550 \mathrm{aB}$ & $3.1850 \mathrm{aA}$ & $0.7325 \mathrm{bB}$ \\
\hline 6.4 & $9.8500 \mathrm{bA}$ & $7.8250 \mathrm{aA}$ & $27.3500 \mathrm{cB}$ & $32.5250 \mathrm{bA}$ & 0.1275 bA & $0.2425 \mathrm{aA}$ & $1.1925 \mathrm{cA}$ & $1.5400 \mathrm{aA}$ \\
\hline 6.7 & $3.3075 \mathrm{dA}$ & $3.5000 \mathrm{bA}$ & $41.7350 \mathrm{aA}$ & $39.5000 \mathrm{aA}$ & $0.0850 \mathrm{bA}$ & $0.0825 \mathrm{aA}$ & $0.6075 \mathrm{dA}$ & $0.5900 \mathrm{bA}$ \\
\hline 7.8 & $5.6500 \mathrm{cA}$ & $1.9000 \mathrm{cB}$ & $33.2250 \mathrm{bA}$ & $24.8250 \mathrm{cB}$ & $0.1200 \mathrm{bA}$ & $0.0850 \mathrm{aA}$ & $1.4975 \mathrm{cA}$ & $0.4000 \mathrm{bB}$ \\
\hline RMG & & & & & & & $\mathrm{TC}$ & \\
\hline 4.8 & $1.4750 \mathrm{cA}$ & $0.0000 \mathrm{bA}$ & $0.175 \mathrm{cA}$ & $0.0000 \mathrm{cA}$ & $0.3125 \mathrm{cA}$ & $0.0000 \mathrm{bA}$ & $12.0475 \mathrm{cA}$ & $9.8800 \mathrm{bA}$ \\
\hline 5.8 & $12.3250 \mathrm{bA}$ & $5.8000 \mathrm{bB}$ & $0.1850 \mathrm{aA}$ & $0.1025 \mathrm{bB}$ & $1.6175 \mathrm{cA}$ & $0.8275 \mathrm{bA}$ & $18.5525 \mathrm{bA}$ & $14.4475 \mathrm{aB}$ \\
\hline 5.9 & $11.2500 \mathrm{bA}$ & $3.8250 \mathrm{bB}$ & $0.1700 \mathrm{aA}$ & 0.0825 bB & $2.1125 \mathrm{bA}$ & $0.5725 \mathrm{bB}$ & $17.5900 \mathrm{bA}$ & $13.7100 \mathrm{aB}$ \\
\hline 6.2 & $2.7750 \mathrm{cB}$ & $16.4250 \mathrm{aA}$ & $0.0425 \mathrm{cB}$ & $0.2250 \mathrm{aA}$ & $0.4800 \mathrm{cB}$ & $2.3950 \mathrm{aA}$ & $14.8650 \mathrm{cA}$ & $14.4000 \mathrm{aA}$ \\
\hline 6.3 & $18.5750 \mathrm{aA}$ & $7.8250 \mathrm{bB}$ & $0.2475 \mathrm{aA}$ & $0.1000 \mathrm{bB}$ & $3.7225 \mathrm{aA}$ & $1.4500 \mathrm{aB}$ & $21.7075 \mathrm{aA}$ & $14.9475 \mathrm{aB}$ \\
\hline 6.4 & $13.2625 \mathrm{bA}$ & $11.6500 \mathrm{aA}$ & $0.2100 \mathrm{aA}$ & $0.2025 \mathrm{aA}$ & $2.6000 \mathrm{BA}$ & $2.0200 \mathrm{aA}$ & $13.1875 \mathrm{cA}$ & $15.0875 \mathrm{aA}$ \\
\hline 6.7 & $4.6323 \mathrm{cA}$ & $5.2000 \mathrm{bA}$ & $0.1100 \mathrm{bA}$ & $0.0775 \mathrm{bA}$ & $0.6375 \mathrm{cA}$ & $0.8850 \mathrm{bA}$ & $14.3150 \mathrm{cA}$ & $13.6375 \mathrm{aA}$ \\
\hline 7.8 & $7.0750 \mathrm{cA}$ & $2.7500 \mathrm{bA}$ & $0.1225 \mathrm{bA}$ & $0.0400 \mathrm{cB}$ & $1.0725 \mathrm{cA}$ & $0.5725 \mathrm{bA}$ & $15.8175 \mathrm{cA}$ & $10.7000 \mathrm{bB}$ \\
\hline RMG & & & & & & & $c$ & \\
\hline 4.8 & $3.6750 \mathrm{bA}$ & $3.0500 \mathrm{bA}$ & $16.1000 \mathrm{bA}$ & $15.1000 \mathrm{aA}$ & $17.1400 \mathrm{bA}$ & $12.2075 \mathrm{cB}$ & $1900.8750 \mathrm{eA}$ & 2061.3600 eA \\
\hline 5.8 & $4.3500 \mathrm{aA}$ & $4.6500 \mathrm{aA}$ & $14.0750 \mathrm{bA}$ & $14.2000 \mathrm{aA}$ & $16.1225 \mathrm{cA}$ & $11.9275 \mathrm{cB}$ & $3566.4350 \mathrm{bA}$ & 2798.8725 bB \\
\hline 5.9 & $5.1750 \mathrm{aA}$ & $4.3500 \mathrm{aA}$ & $15.8250 \mathrm{bA}$ & $15.9500 \mathrm{aA}$ & $16.1750 \mathrm{cA}$ & $12.0500 \mathrm{cB}$ & $2388.9400 \mathrm{dA}$ & $2303.5875 \mathrm{dA}$ \\
\hline 6.2 & $5.4500 \mathrm{aA}$ & $2.9750 \mathrm{bB}$ & $16.4500 \mathrm{bA}$ & $12.5500 \mathrm{aB}$ & $15.6700 \mathrm{dA}$ & $13.0050 \mathrm{bB}$ & $2969.9100 \mathrm{cA}$ & $2668.8700 \mathrm{cB}$ \\
\hline 6.3 & 3.5125 bA & $2.1750 \mathrm{bB}$ & $15.0725 \mathrm{bA}$ & $11.3250 \mathrm{aB}$ & $17.3975 \mathrm{bA}$ & $11.8875 \mathrm{cB}$ & $3808.3650 \mathrm{aA}$ & $3516.6575 \mathrm{aB}$ \\
\hline 6.4 & $2.4500 \mathrm{bA}$ & $3.8750 \mathrm{aA}$ & 9.1750 cB & $13.8250 \mathrm{aA}$ & $14.6400 \mathrm{eB}$ & $16.7725 \mathrm{aA}$ & $2960.1275 \mathrm{cA}$ & $2332.4725 \mathrm{~dB}$ \\
\hline 6.7 & $5.2725 \mathrm{aA}$ & $3.000 \mathrm{bB}$ & 20.8375 aA & $15.3000 \mathrm{aB}$ & $13.5150 \mathrm{fA}$ & $11.9300 \mathrm{cB}$ & $3853.2425 \mathrm{aA}$ & $2425.5950 \mathrm{~dB}$ \\
\hline 7.8 & $3.6000 \mathrm{bA}$ & $2.5250 \mathrm{bA}$ & $18.1250 \mathrm{aA}$ & $13.2500 \mathrm{aB}$ & $17.7500 \mathrm{aA}$ & $16.9375 \mathrm{aB}$ & $3408.5175 \mathrm{Ba}$ & $2894.7400 \mathrm{bB}$ \\
\hline
\end{tabular}

*Lower case letters compare the RMGs within each season in the column. * Capital letters compare the times within each RMG on the line. *Averages followed by the same letter do not differ with a $5 \%$ probability of error by the Tukey probability matrix. RMG: relative maturity group; PH: total plant height; FPIH: first pod insertion height; NP3: number of pods with, three grains; PM2: pods mass of two grains; NLB: number of lateral branches; NRNMS: number of reproductive nodes on the main stem; PM3: pods mass of three grains; NPLB1: number of pods on lateral branches of one grain; TNNMS: total number of nodes on the main stem; NRNLB: number of reproductive nodes on the lateral branches; NPLB2: number of pods on lateral branches of two grains; NPLB3: number of pods on lateral branches of three grains; TNNLB: number of total nodes on the lateral branches; NPMS: number of pods on the main stem; PMLB1: pod mass on lateral branches with one grain; PMLB2: pod mass on lateral branches with two grains; NPLB: number of pods on the lateral branches; LBL: lateral branch length; ; PMLB3: pod mass on lateral branches with three grains; TGM: total grain mass per plant; NP1: number of pods with one grain; NP2: number of pods with two grains; TSM: thousand seed mass; GY: grain yield. 
Table 4. Duration of the subperiods, S-VE: sowing - emergence; VE-R1: emergence - R1; R1-R3; R3-R5; R5R7; R8-C: R8-harvest; R1-R5; R1-8 and VE-R8: emergence - R8.

\begin{tabular}{|c|c|c|c|c|c|c|c|c|c|}
\hline \multicolumn{10}{|c|}{ Jan 5} \\
\hline RMG & S-VE & VE- R1 & R1-R3 & R3-R5 & R5-R7 & R8-C & R1-R5 & R1-R8 & VE-R8 \\
\hline 4.8 & 5 & 52 & 14 & 29 & 15 & 14 & 43 & 58 & 110 \\
\hline 5.8 & 5 & 56 & 17 & 27 & 20 & 9 & 44 & 64 & 120 \\
\hline 5.9 & 5 & 59 & 19 & 26 & 18 & 9 & 45 & 63 & 122 \\
\hline 6.2 & 5 & 60 & 18 & 28 & 17 & 5 & 46 & 63 & 123 \\
\hline 6.3 & 5 & 62 & 19 & 28 & 15 & 7 & 47 & 62 & 124 \\
\hline 6.4 & 5 & 65 & 22 & 25 & 21 & 14 & 47 & 68 & 133 \\
\hline 6.7 & 5 & 71 & 22 & 24 & 18 & 16 & 46 & 64 & 135 \\
\hline 7.8 & 5 & 79 & 23 & 33 & 18 & 12 & 56 & 74 & 153 \\
\hline \multicolumn{10}{|c|}{ Jan 22} \\
\hline RMG & S- VE & VE-R1 & R1-R3 & R3-R5 & R5-R7 & $\mathrm{R} 8-\mathrm{C}$ & R1-R5 & R1-R8 & E-R8 \\
\hline 4.8 & 6 & 39 & 16 & 18 & 19 & 15 & 34 & 53 & 92 \\
\hline 5.8 & 6 & 42 & 18 & 17 & 18 & 15 & 35 & 53 & 95 \\
\hline 5.9 & 6 & 42 & 18 & 18 & 17 & 14 & 36 & 53 & 95 \\
\hline 6.2 & 6 & 44 & 20 & 17 & 17 & 12 & 37 & 54 & 98 \\
\hline 6.3 & 6 & 44 & 21 & 18 & 15 & 12 & 39 & 54 & 98 \\
\hline 6.4 & 6 & 46 & 22 & 17 & 15 & 10 & 39 & 54 & 100 \\
\hline 6.7 & 6 & 50 & 22 & 22 & 22 & 12 & 44 & 66 & 116 \\
\hline 7.8 & 6 & 56 & 25 & 15 & 15 & 10 & 40 & 55 & 111 \\
\hline
\end{tabular}

As the number of reproductive nodes on the main stem (NRNMS) increases, the number of total nodes on the main stem (TNNMS) also increases. As the latter tends to increase, influences the increment in the total grain mass, which is influenced by the number of pods per plant. For the number of total reproductive nodes on the lateral branches, the moment the branch increases, the branch length increases and there is a greater total grain mass (TGM). In order to increase the number of pods on the main stem (NPMS), there is an increment in the number of pods with one and two grains (NP1 and NP2) and a reduction in the number of pods with 4 grains (NP4), which may be related to the breeding of the soybean crop, where there is a tendency to select genotypes with pods with fewer seeds. The same is true for the number of pods with two grains (NP2).

For the second sowing season, the linear correlation (Figure 2) shows that for grain yield (GY), as it increases, it tends to decrease the number of pods with two grains (NP2), indirectly tends to maximize other yield components although they were not significant by the model. The total plant height (PH), as the increase occurs, tends to increase the first pod insertion height (FPIH) and increase the total grain mass (TGM), which may be related to a better source/drain ratio resulting in greater grain mass. To increase the number of lateral branches (NLB), there is an increase in the number of reproductive nodes on the lateral branches (NRNLB), lateral branch length (LBL), which results in an increase in the total grain mass (TGM). To increase the total number of nodes on the main stem (TNNMS), there is the maximization of the total grain mass (TGM), which may be related to the number of pods present on the main stem. To increase the number of pods on the main stem (NPMS), there is an increase in the number of pods with three grains (NP3). For the lateral branch length (LBL), as it increases, it tends to increase the total grain mass, due to the greater number of pods available. 


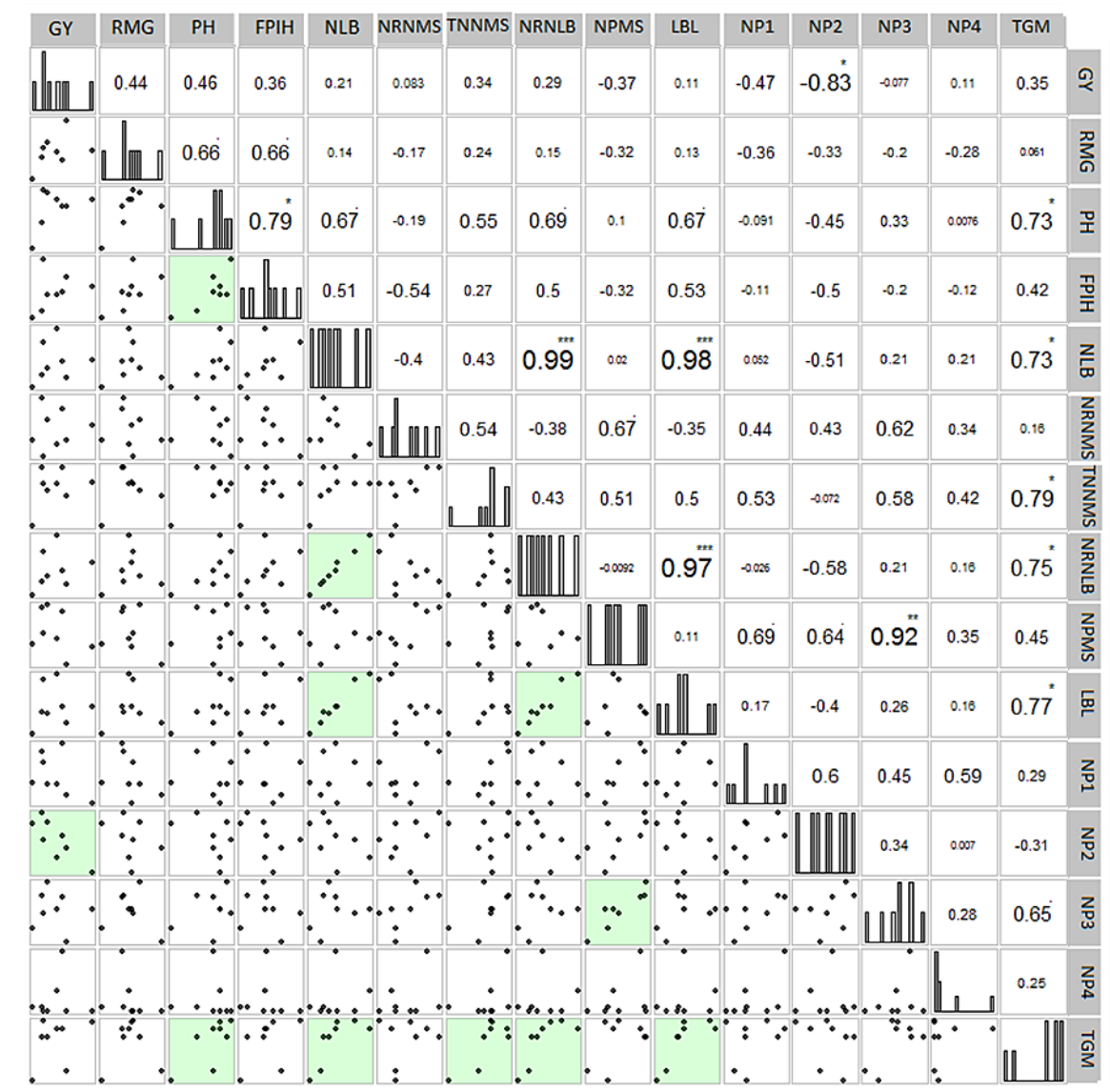

Figure 2. Phenotypic linear correlation for the second sowing time $\mathrm{x}$ relative maturity group.

*significant at $5 \%$ probability by t test. GY: grain yield $\mathrm{kg} / \mathrm{ha}^{-1}$; RMG: relative maturity group; PH: total plant height; FPIH: first pod insertion height; NLB: number of lateral branches; NRNMS: number of reproductive nodes on the main stem; TNNMS: total number of nodes on the stem nodes; NRNLB: number of reproductive nodes on the lateral branches; NPMS: number of pods on the main stem; LBL: lateral branch length; NP1, NP2, NP3, NP4: number of pods with one, two, three and four grains; TGM: total grain mass per plant.

The climatic conditions (Figure 5) showed that throughout the vegetative period of both sowing seasons, there was an accumulated rainfall volume of $521 \mathrm{~mm}$, being well distributed throughout this period, at the end of this subperiod we can observe that after the emergence, temperatures occurred below $15{ }^{\circ} \mathrm{C}$, however they did not compromise the flowering sub-period, pod emission and grain filling, therefore, not influencing the grain yield of the respective cultivars.

The linear correlation (Figure 3) represents the variables responsible for soybean growth, so when we sow cultivars with different RMGs in the same region, the higher the RMG, the longer the development cycle of this cultivar and the lower the RMG, the smaller the cycle (Zanon et al., 2015). Thus, the results include what is in the literature, as late sowing occurs, tends to reduce the number of days of the crop between VE/R1, R3/R5, R1/R5, R1/R8, cycle and TSM. As the RMG increases, there is an increment in the days between the soybean stages, which are VE/R1, R1/R3, R1/R5, cycle and grain yield. This is due to the higher the RMG, the plant needs more photoperiod to complete its cycle, it tends to have a longer vegetative and reproductive period, which ultimately results in greater grain yield. For the VE stage, as the days of crop emergence increase, it directly influences the reduction of the vegetative period until the reproductive period of the crop, mainly VE/R1, R3/R5, R1/R5, R1/R8, cycle and TSM. The increase in days of the R3/R5 stage consequently results in an increase in the days of R1/R5, R1/R8, cycle and also the TSM. The increase in the days of R5/R7, tends to increase the period of days of the stages of R1/R8. According to Peske et al. (2012) at the end of the phenological stage R5 there is $80 \%$ of the accumulation of dry matter in the seeds, therefore, it appears that there was a greater accumulation of photoassimilates and this is directly influenced by the vegetative structures that are responsible for developing reserve organs of photoassimilated products that will be translocated to the grains during the filling period (Rodrigues, Alvim, Brito, Brandão, \& Gomes, 2011). 


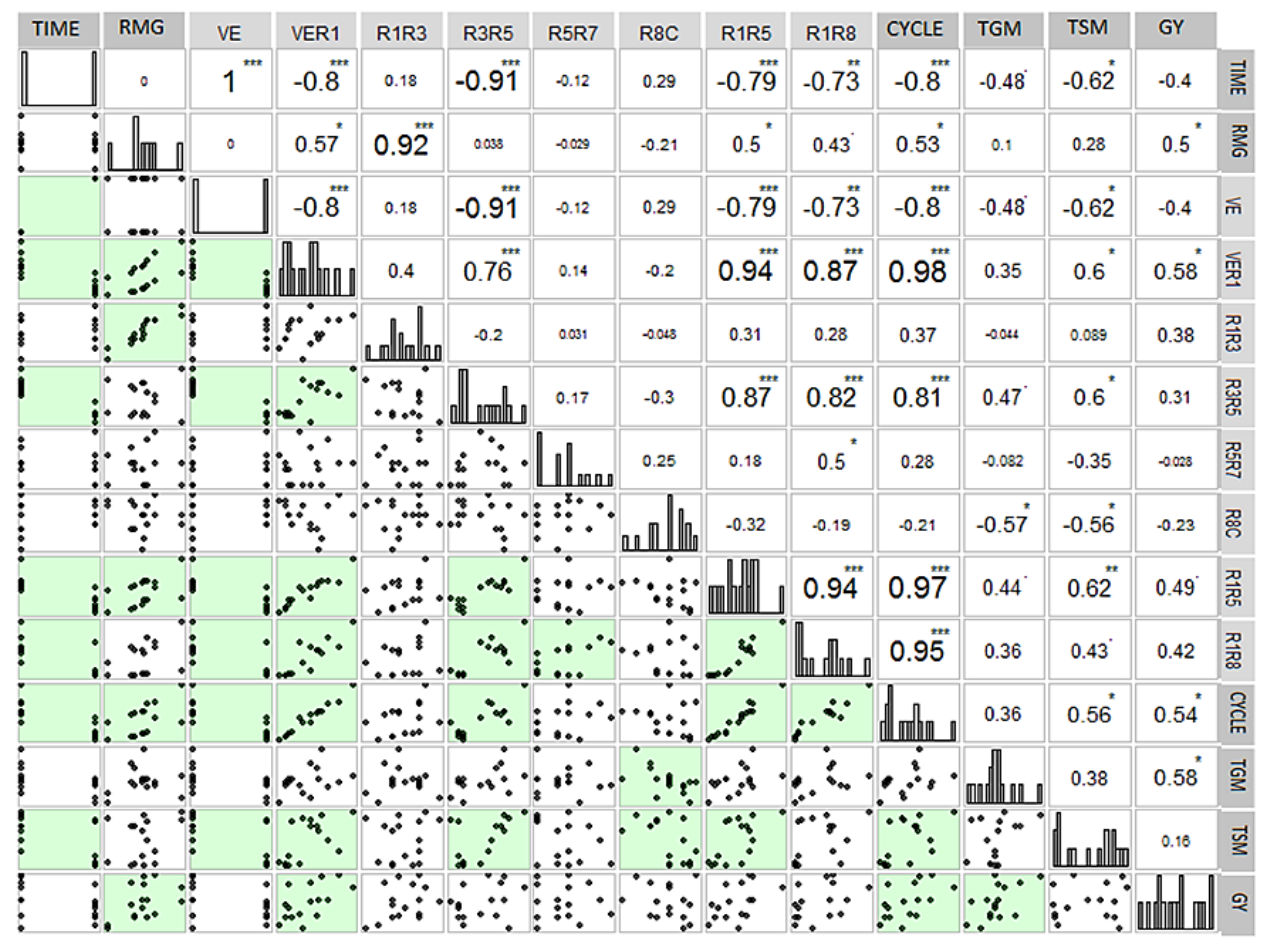

Figure 3. Phenotypic linear correlation for soybean growth $x$ relative maturity group.

*significant at $5 \%$ probability by t test. RMG: relative maturity group; VE: emergence; VER1: emergence - R1; R1R3: R1 - R3; R3R5: R3 - R5; R5 - R7: R5 - R7; R8 - C: R8 - Harvest; R1R5: R1-R5; R18: R1-8; VE - R8: emergence - R8; TGM: total grain mass; TSM: thousand seed mass; GY: grain yield.

When there is an increase in the period from $R 8$ until harvest (R8/C) this increase tends to cause a reduction in TGM and TSM, because the grains were constantly exposed to various variations in the environment, which can compromise the quality of this seed. As the period of R1/R5 increases, the period of R1/R8, Cycle and TSM increases. For this period there is a volume of precipitation of $180 \mathrm{~mm}$, which is extremely important, because in this subperiod there is the differentiation of vegetative structures in reproductive, flower emission, pod formation and grain filling, where situations of water stress may result in the miscarriage of flowers, pods or a reduction in the rate of grain filling depending on its intensity, duration and period of occurrence.

In the same way that the period of R1/R8 increases, there is an increase in the cycle, and with the increase of the cycle there is a tendency to increase the TSM and grain yield (GY). The increase in TGM contributes to the increase in grain yield.

The dendrogram (Figure 4) taking into account the average and deviations of the distance shows the similarity of treatments for the first sowing period, regardless of the variables, what we can analyze is that the treatments were divided into two large groups, for blue there was an affinity between treatments 5.8 and 7.8 , this is due to the fact that between the two treatments, some variables did not show significant differences by the means test (table 3 ), and they did not directly influence yield. For treatments 6.7 and 6.3 , due to their proximity to the cycle, similarity in plant height occurred, which resulted in a greater number of pods with three grains and yield. The cultivars with RMG 6.4 and 6.2 , also due to their proximity to the cycle, which differs from the previous one, which shows significance for the total grain mass. The other group of cultivars was with RMG 5.9 and 4.8, for these treatments the variables with the total number of nodes on the main stem and branches stood out, but not influencing the yield, so it can be said that there was a smaller number of reproductive nodes for these cultivars. 


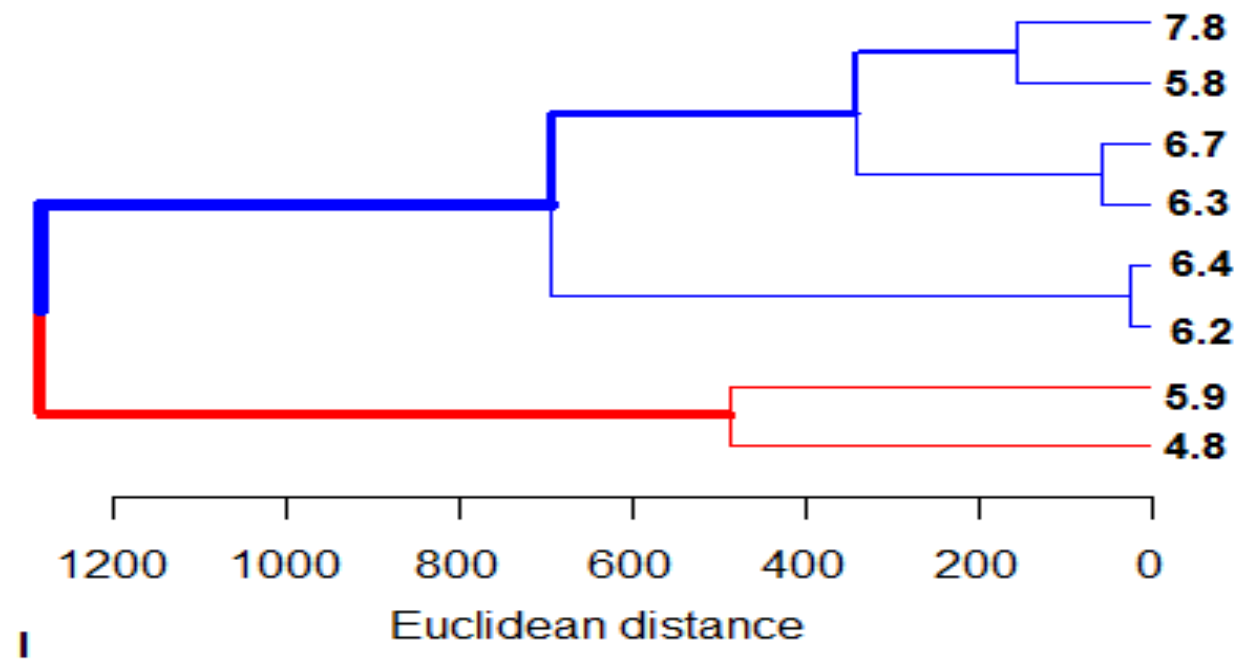

Figure 4. Dendrogram obtained for linear for the effects of the first sowing season $x$ relative maturity group, using the average Euclidean algorithm with all measured variables.

For the second sowing season, (Figure 5) the dendrogram shows that from the average and the distance deviations, the treatments that showed the greatest similarity were the cultivars with RMG 5.9 and 6.4, mainly due to the issue of the number of pod with one and two grains. For cultivars with RMG 5.8 and 7.8, this similarity occurred in quite a few variables, but plant height and grain yield stand out, which may have been caused by some climatic adversity.

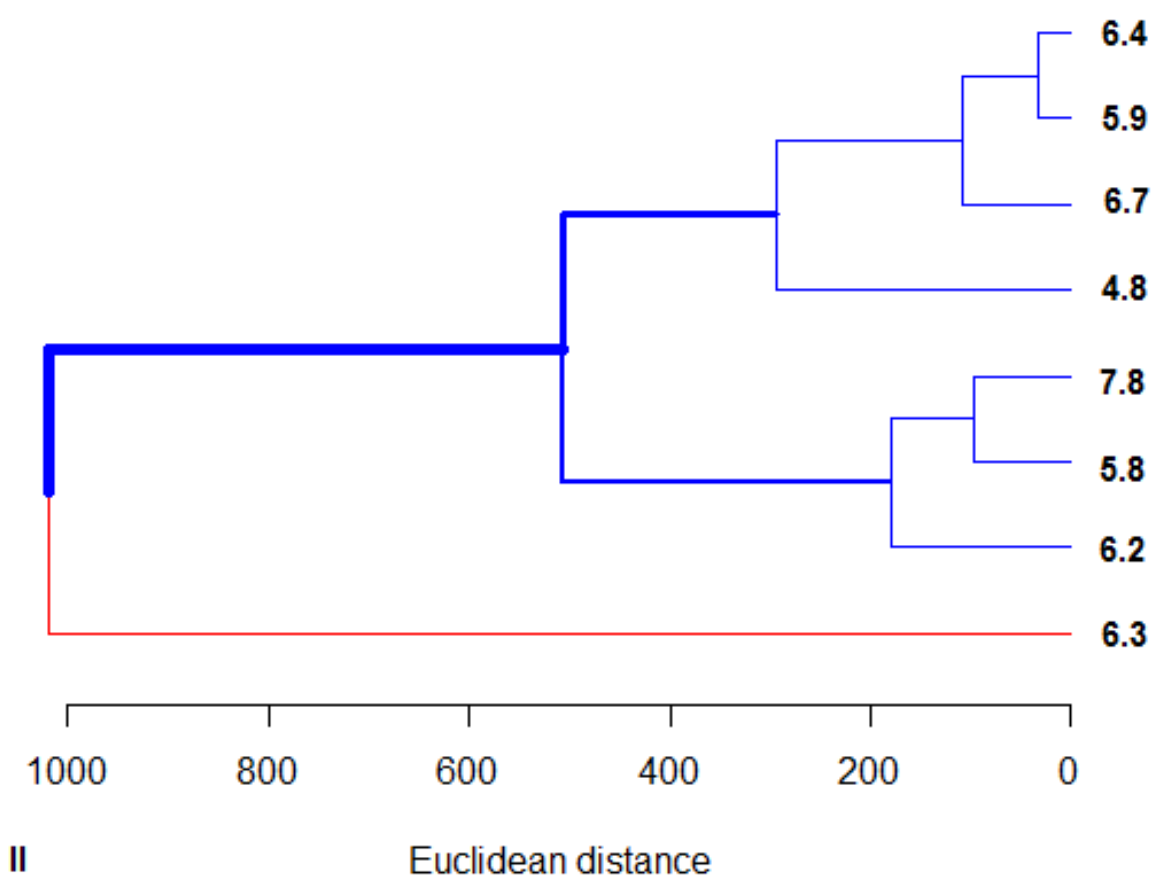

Figure 5. Dendrogram obtained for linear for the effects of the second sowing season $\mathrm{x}$ relative maturity group, using the average Euclidean algorithm with all measured variables.

The BIPLOT graph (Figure 6) shows the variable/treatment ratio, with the first sowing time and the cultivars with the highest RMG, being 6.4, 6.7 and 7.8, showing the best results for the variables analyzed. These cultivars, in general, have a longer duration of the crop cycle, thus increasing the number of days between the phenological stages of the crop, resulting in higher grain yield in the end. The cultivars with the smallest RMG tend to reduce the cycle, resulting in less total grain mass and thousand seed mass. 
PCA - Biplot

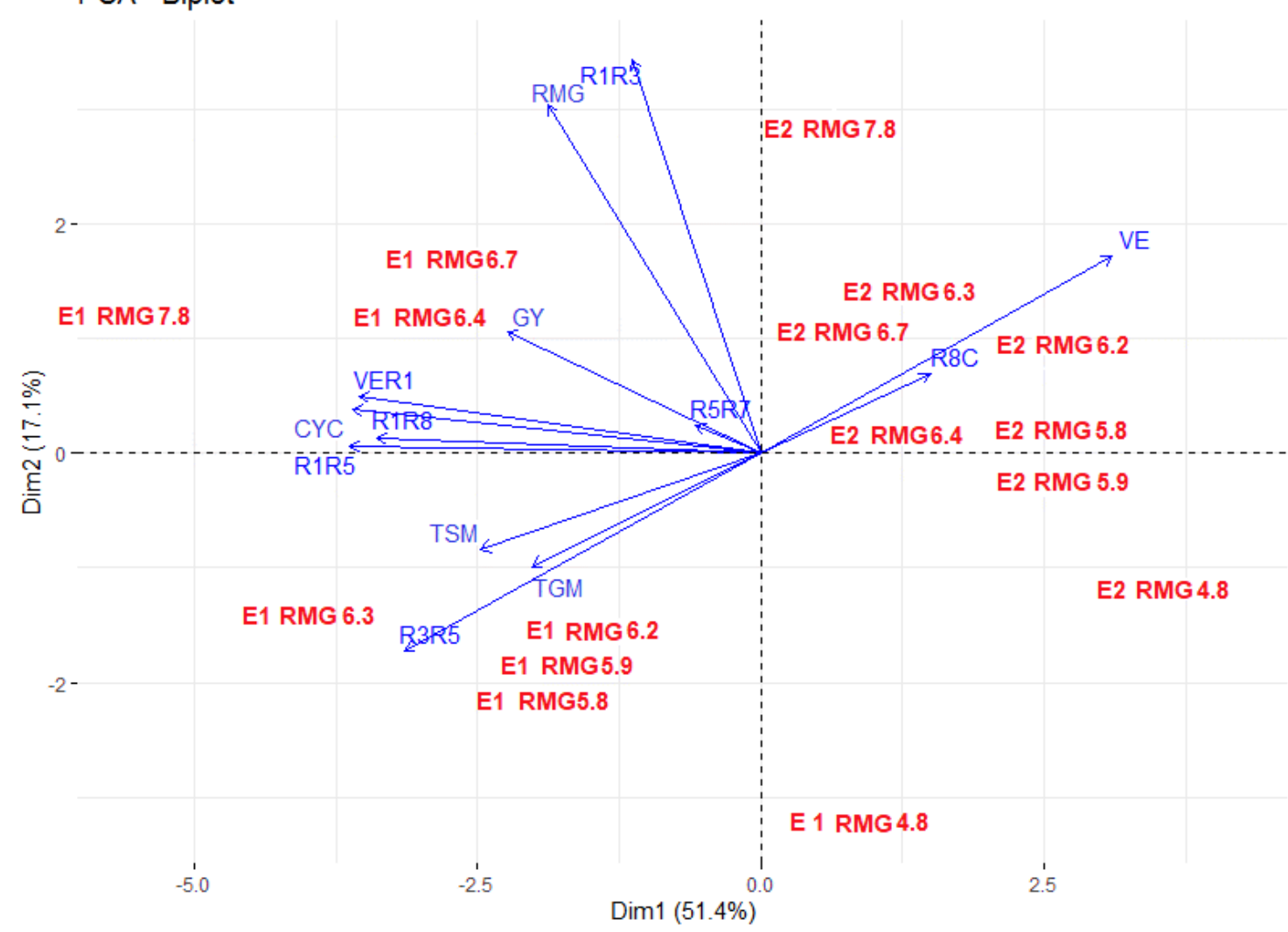

Figure 6. Biplot principal components based on the effects of the interaction between non-preferred sowing times of soybean $x$ relative maturity groups, for the variables VE: emergence; VER1: emergence R1; R1R3: R1 - R3; R3R5: R3 - R5; R5R7: R5 - R7; R8C: R8 - harvest; R1R5: R1-R5; R18: R1-8; VER8: emergence - R8; CYC: cycle; RMG: relative maturity group; TGM: total grain mass; TSM: thousand seed mass; GY: grain yield.

\section{CONCLUSIONS}

The most productive relative maturity group is 6.3 being sown in the first non-preferential season for soybeans in Rio Grande do Sul.

The second sowing time changed the dynamics of association of the measured variables, with changes in the cycle, reductions in the vegetative and reproductive period.

The agronomic attributes that are decisive for soybean yield in a non-preferential season are intrinsic to the phenology and response of the relative maturity groups to the photoperiod.

\section{REFERENCES}

Braccini, A. L., Motta, I. S., Scapim, C. A., Braccini, M. C. L., Ávila, M. R., \& Schuab, S. R. P. (2003). Semeadura da soja no período de safrinha: potencial fisiológico e sanidade das sementes. Revista Brasileira de Sementes, 25(1), 76-86. https://doi.org/10.1590/s0101-31222003000100013

Carvalho, I., Peter, M., Demari, G. H., Hutra, D. J., Conte, G. G., Zimmermann, C. S., ... Sangiovo, J. P. (2021). Biometric approach applied to soybean genotypes cultivated in Rio Grande do Sul, Brazil. Agronomy Science and Biotechnology, 7, 1-11. https://doi.org/10.33158/asb.r118.v7.2021

CONAB - Companhia Nacional de Abastecimento. (2019). Série histórica: soja. Brasília, DF: CONAB. Retrieved from https://www.conab.gov.br/conabweb/download/safra/SojaSerieHist.xls

Fehr, W. R., \& Caviness, C. E. (1977). Stage of soybean development (Special Re). Ames: lowa State University. Retrieved from http://lib.dr.iastate.edu/specialreports/87 
Ferreira, L. L., Ricardo Viana de Carvalho, P., Fernandes, M. de S., Silva, J. G., Ricardo Carvalho, I., \& Lautenchleger, F. (2020). Neural network and canonical interrelationships for the physiological aspects of soybean seedlings: effects of seed treatment. Agronomy Science and Biotechnology, 6, 1-11. https://doi.org/10.33158/asb.r116.v6.2020

Frota, R. T., Carvalho, I., Demari, G. H., Loro, M. V., Hutra, D. J., Lautenchleger, Francine, ... Aumonde, T. Z. (2020). Molybdenum and potassium in the foliar fertilization and seed quality in the soybean. Agronomy Science and Biotechnology, 6(V), 1-9. https://doi.org/10.33158/asb.r117.v6.2020

Hanway, J. J., \& Thompson, H. E. How a soybean plant develops. Ames: lowa State University of Science and Technology: Cooperative extension, service, 20p (Special Report, 53). https://lib.dr.iastate.edu/cgi/viewcontent.cgi ?article=1050\&context=specialreports

Hanyu, J., Costa, S., Cecon, P., \& Matsuo, É. (2020). Genetic parameters estimate and characters analysis in phenotypic phase of soybean during two evaluation periods. Agronomy Science and Biotechnology, 6(2008), 1-12. https://doi.org/10.33158/asb.r104.v6.2020

Meotti, V. G., Raphael, G. B., Beche, R. S. E., \& Munaro, L. B. (2012). Épocas De Semeadura E Cultivares De Soja Na Produção De Forragem. Bioscience Journal, 28(4), 557-565.

Mundstock, C. M., \& Thomas, A. L. (2005). Soja: fatores que afetam o crescimento e o rendimento de grãos. Biblioteca Setorial Da Faculdade de Agronomia Da UFRGS, 31.

Pandey, J. P., \& Torrie, J. H. (1973). Path Coefficient Analysis of Seed Yield Components in Soybeans ( Glycine $\max$ (L.) Merr.) 1 . Crop Science, 13(5), 505-507. https://doi.org/10.2135/cropsci1973.0011183x001300050004x

Peixoto, C. P., Câmara, G. M. de S., Martins, M. C., Marchiori, L. F. S., Guerzoni, R. A., \& Mattiazzi, P. (2000). Épocas de semeadura e densidade de plantas de soja: I. Componentes da produção e rendimento de grãos. Scientia Agricola, 57(1), 89-96. https://doi.org/10.1590/s010390162000000100015

Rodrigues, K., Alvim, D. T., Brito, C. H., Brandão, A. M., \& Gomes, L. S. (2011). Redução da área foliar em plantas de milho na fase reprodutiva. Revista Ceres, 58(4), 413-418.

Rodrigues, O., Didonet, A. D., Lhamby, J. C. B., Bertagnolli, P. F., \& Luz, J. S. (2001). Resposta quantitativa do florescimento da soja à temperatura e ao fotoperíodo. Pesquisa Agropecuária Brasileira, 36(3), 431-437. https://doi.org/10.1590/s0100-204×2001000300006

Soares, M. M., Sediyama, T., \& Matsuo, É. (2020). Efficiency and responsiveness of using phosphorus and molecular diversity among soybean cultivars. Agronomy Science and Biotechnology, 6, 1-11. https://doi.org/10.33158/asb.r108.v6.2020

Streck, N. A., Paula, G. M., Camera, C., Menezes, N. L., \& Lago, I. (2008). Estimativa do plastocrono em cultivares de soja. Bragantia, 67(1), 67-73. https://doi.org/10.1590/s0006-87052008000100008

Ting-ting, W., Jin-yu, L., Cun-xiang, W., Shi, S., Ting-ting, M., Bing-jun, J., Wen-sheng, W., Tian-fu, H. (2015). Analysis of the independent- and interactive-photo-thermal effects on soybean flowering. Journal of Integrative Agriculture, 14(4), 622-632. https://doi.org/10.1016/S2095-3119(14)60856-X

Weber, P. S., (2017). Componentes de rendimento e grupos de maturidade relativa que influenciam o potencial de produtividade em soja. 34p. Course conclusion paper (Graduation in Agronomy). Universidade Federal de Santa Maria, Santa Maria - RS.

Zanon, A. J., Winck, J. E. M., Streck, N. A., Rocha, T. S. M., Cera, J. C., Richter, G. L., ... Marchesan, E. (2015). Desenvolvimento de cultivares de soja em função do grupo de maturação e tipo de crescimento em terras altas e terras baixas. Bragantia, 74(4), 400-411. https://doi.org/10.1590/1678-4499.0043 
Zanon, A. J.; Silva, M. R.; Tagliapietra, E. L.; Cera, J. C.; Bexaira, K. P.; Richter, G. L.; Duarte-junior, A. J.; Rocha, T. S. M.; Weber, P. S.; Streck, N. A. (2018). Ecofisiologia da soja visando altas produtividades. Santa Maria, RS: Palotti.

Received: January 21, 2021.

Accepted: March 7, 2021.

Published: April 24, 2021.

\section{English by: Francine Lautenchleger.}

